\title{
AN ANALYSIS OF STUDENTS' ATTITUDES TOWARDS MATHEMATICAL PROBLEM SOLVING ABILITY
}

\author{
Hella Jusra ${ }^{1}$, Luthfiyah Aulia Iskandar ${ }^{2}$ \\ ${ }^{1}$ Universitas Muhammadiyah Prof. DR. HAMKA, Jl. Tanah Merdeka, Jakarta, Indonesia \\ hella.jusra@uhamka.ac.id \\ ${ }^{2}$ Universitas Muhammadiyah Prof. DR. HAMKA, Jl. Tanah Merdeka, Jakarta, Indonesia \\ luthfiyahauliaiskandar.math@gmail.com
}

\begin{abstract}
This study aims to identify the attitudes of students on the ability to solve problems with mathematics. The attitudes of students evaluated in this study include self-confidence, anxiety, enthusiasm, and self-regulated mathematics learning. The research subjects were 79 students in $8^{\text {th }}$ grade. The researcher re-concentrated on three students from all of them, who had mathematical problem-solving skills in the high, medium, and low groups. These subjects were selected from students who focused on problem-solving mathematical skills, questionnaires on the attitudes of students, and interviews with researchers. The instruments used to collect were an instrument of problem-solving mathematical ability and an instrument of students' attitudes in the form of student attitudes towards mathematics questionnaire. The research method used is descriptive qualitative. The findings have shown that the majority of students are balanced between excited and unexcited on mathematics. The majority reason for students who are enthusiastic about mathematics is that they can improve their abilities, talents, and knowledge. Others have different explanations such as having the resources; formulas and problems, making them feel challenged; thinking that mathematics is important. The majority of students had a low category of self-confidence and anxiety towards mathematics, and had a moderate level of enthusiasm in mathematics and self-regulated learning.
\end{abstract}

\section{ARTICLE INFORMATION}

\begin{tabular}{lll}
\hline Keywords & & Article History \\
\cline { 1 - 1 } Self confidence & & Submitted Oct 14, 2020 \\
Mathematics Anxiety & & Revised Nov 19, 2020 \\
Enthusiasm & Accepted Nov 22, 2020 \\
Self-Regulation & \\
Problem Solving & \\
\hline Corresponding Author & \\
\hline
\end{tabular}

Hella Jusra

Universitas Muhammadiyah Prof. DR. HAMKA

Jl. Tanah Merdeka, Jakarta, Indonesia

Email: hella.jusra@uhamka.ac.id

\section{How to Cite}

Jusra, H. \& Iskandar, L.A. (2020). An Analysis of Students' Attitudes Towards Mathematical Problem Solving Ability. Kalamatika: Jurnal Pendidikan Matematika, 5(2), 181-194. 


\section{INTRODUCTION}

The majority of previous studies focused on students' attitudes towards mathematics, but in this analysis, researchers would identify the attitudes of $8^{\text {th }}$ grade students and the ability of students to solve mathematical problems. Three variables affect students' lack of mathematical skills, they may be from educators, students themselves, and environmental variables (Atan \& Kasmin, 2018). Student variables, such as the level of intellect, preferences, skills, and attitudes, derive from the students themselves. Attitude is one of the considerations found in student variables. As a consequence of one's experience, it is a psychological path that influences the way an individual views circumstances, objects, or students, and how students react (Rajkumar \& Hema, 2019). The attitudes of students need to be addressed because they will decide how students judge and react to lessons in mathematics. Attitude is one of the main variables in learning mathematics for the success or failure of students. Mathematics may be described as an abstract principle or idea whose reasoning is deductively carried out so that students can approach mathematics differently. Mazana, Montero, and Casmir (2018) also said that learning attitudes can be responded to either positively or negatively by students. If learning outcomes are successful for the student, then the attitude of the student towards learning is positive. Similarly, if the attitude of the student during the learning process is negative, then the results cannot embrace learning well so that it affects learning outcomes. Hence, the attitude of the student in learning is very relevant.

Student attitudes towards mathematics are a key factor that can influence student success (Waheed \& Mohamed, 2011). It follows that attitude is a significant factor, the effect of which is on the condition of students who can create positive or negative attitudes in mathematics that cannot be prevented. (Mazana et al., 2018). Gonzalez also said that what affects student actions in a willingness to learn is student attitudes (Escalera Chávez, Moreno García, \& Rojas Kramer, 2018). From these statements, student attitudes can impact their success in solving mathematical problems. Students who are accustomed to mathematical problem solving will gradually understand that by memorizing existing formulas, mathematics is not a sufficient science, but that any idea that is taught needs to be practiced and will be useful for life. In mathematics, problem-solving is also a good strategy for learners to grasp the substance of the lesson and increase student activity in relating their knowledge to real-life comprehension problems. One of the aims of studying mathematics in schools is to allow students to find solutions to mathematical problems and their processes.

Students with a positive attitude towards mathematics are known to be better able to solve mathematical problems than students with negative attitudes towards mathematics. We 
may conclude that they appear to have higher abilities to solve mathematical problems. The success of mathematical problem-solving skills will be affected by attitudes. This is reinforced by the view of Fitzpatrick and Van De Walle that values and attitudes affect the problemsolving behavior of students, so this is an area that needs to be strengthened (Sezgin memnun $\&$ ÇOBAN, 2015). Akinmola then suggests that there are five interrelated components in the creation of the mathematical problem-solving ability of students, namely principles, skills, methods, attitudes, and metacognition. (Akinmola, 2014). This is supposed to characterize the attitudes of students in terms of the mathematical problem-solving ability of students. Following the goals of this study, that is, to define the attitudes of students in terms of the mathematical problem-solving ability of students. In this analysis, the attitude measuring theory used is the ABC model or the tripartite model. The ABC model conceptualizes attitudes as a synthesis of three components (Mazana, et.al., 2018), namely 1) affecting with a) selfconfidence, b) anxiety in mathematics, and c) enthusiasm; 2) behavior with a) intrinsic motivation; and 3) cognition with a) perceived benefits. However, in this study, researchers focused more on the affecting as in the first components. Self-confidence, math anxiety, and math enthusiasm are the components of it. Also, researchers added self-regulated learning to this component. Since the attitudes of students require self-regulation in their learning, so the purpose to this research is to describe students' attitude towards ability of mathematical problem solving.

\section{METHOD}

The research method used in this research is the descriptive qualitative method. Qualitative research methods are often called naturalistic methods. According to Strauss and Corbin, they are a type of research in which the resulting findings cannot be achieved using statistical procedures or other means of quantification (F. Hidayat, Akbar, \& Bernard, 2018). 79 students in $8^{\text {th }}$ grade were the subjects of this research. The researchers focused on three students in the high, medium, and low groups with mathematical problem-solving ability. The method used was a mathematical problem-solving ability test for students and a questionnaire on the attitudes of students towards mathematics. In this research, students were asked questions about the mathematical problem-solving ability that consisted of 8 test questions in the form of explanations of problem-solving issues about the topic circles to measure the mathematical problem-solving ability of students (Ariani, Hartono, \& Hiltrimartin, 2017) whose scores were then classified into several groups as seen in table 1. 
Table 1. Groups of Students' Problem-Solving Ability

\begin{tabular}{lc}
\hline Students' Score & Groups of assessment \\
\hline $81-100$ & Very Good \\
$61-80$ & Good \\
$41-60$ & Enough \\
$21-40$ & Less \\
$0-20$ & Very Less \\
\hline
\end{tabular}

The researchers administered a questionnaire on the attitudes of students towards mathematics to test the attitudes of students towards learning mathematics. The student attitude questionnaire consists of 2 parts, with 5 questions about attitudes in the first part, while 31 statements are focused on aspects of self-confidence, math anxiety, math enthusiasm, and selfregulated learning in the second part. The outcomes of the attitude questionnaire measurement scores of the students were classified into five categories, following Azwar (2012) as shown in table 2.

Table 2. Categorical Levels on the Student Questionnaire

\begin{tabular}{lc}
\hline Score & Category \\
\hline$\mu \leq-1,5 \sigma$ & Very Low \\
$-1,5 \sigma<\mu \leq-0,5 \sigma$ & Low \\
$-0,5 \sigma<\mu \leq+0,5 \sigma$ & Moderate \\
$+0,5 \sigma<\mu \leq+1,5 \sigma$ & High \\
$+1,5 \sigma<\mu$ & Very High \\
\hline
\end{tabular}

Three students with low, medium, and high abilities were selected based on the score of mathematical problem-solving ability. They then would be interviewed according to both instruments, mathematical problem-solving test and questionnaire to clarify the results of the object under study.

\section{RESULTS AND DISCUSSION}

From the analysis, $40.5 \%$ of students are enthusiastic about learning mathematics and $16.5 \%$ of students are not. However, most of them consider that they feel excited about mathematics sometimes. This can be seen from the number of students that is $43 \%$ of students.

For students who are passionate about mathematics, the greatest explanation is that they will develop their skills, abilities and knowledge. Others have numerous reasons, such as having the resources; formulas and problems making them feel challenged; loving counting; believing that mathematics is essential, precise science, enjoyable, easy and curious. Little learners have no good reason to be passionate about mathematics.

Mathematics can also be challenging for students who are willing to learn mathematics. Most of them assume that they have issues with math questions itself, a method to solve them, and another rationale is about working time. Students feel anxious when they can't solve the math problems well due to the time determined to work on the problems. Besides, they have numerous other issues, such as mathematics material problems, mathematical formula 
problems, misunderstanding or lack of comprehension, because their mathematics teachers feel less enthusiastic, unable to count, find mathematics challenging, feel less intelligent, feel less vigilant, feel headaches and some do not even offer specific explanations for their problems. These challenges are also encountered for the students are not interested in mathematics. The difference is that they take into account these as problems that they cannot solve.

Every student must have felt something that came to him when he was learning mathematics. Most of the eighth-grade students who are studying mathematics feel headaches. Some students feel "dizzy but happy", there are students who feel headaches because learning mathematics is complicated, and so on. Apart from that reason, students also have other feelings while studying mathematics, including feeling happy, excited, confused, challenged, lazy, difficult, bored, easy, patient, feeling themselves understanding math, confident, sleepy, curious and feel ordinary. In this study, researchers focused more on students' attitudes on the components of affect such as:

\section{Self Confidence}

Self-confidence is a personality that involves trust in skills, optimism, responsibility, and bravery. Self-confidence can be defined as a belief that outcomes can be produced, goals accomplished or tasks performed competently (Ibrahim, 2018). The proportion of students' confidence level can be seen in figure 1.

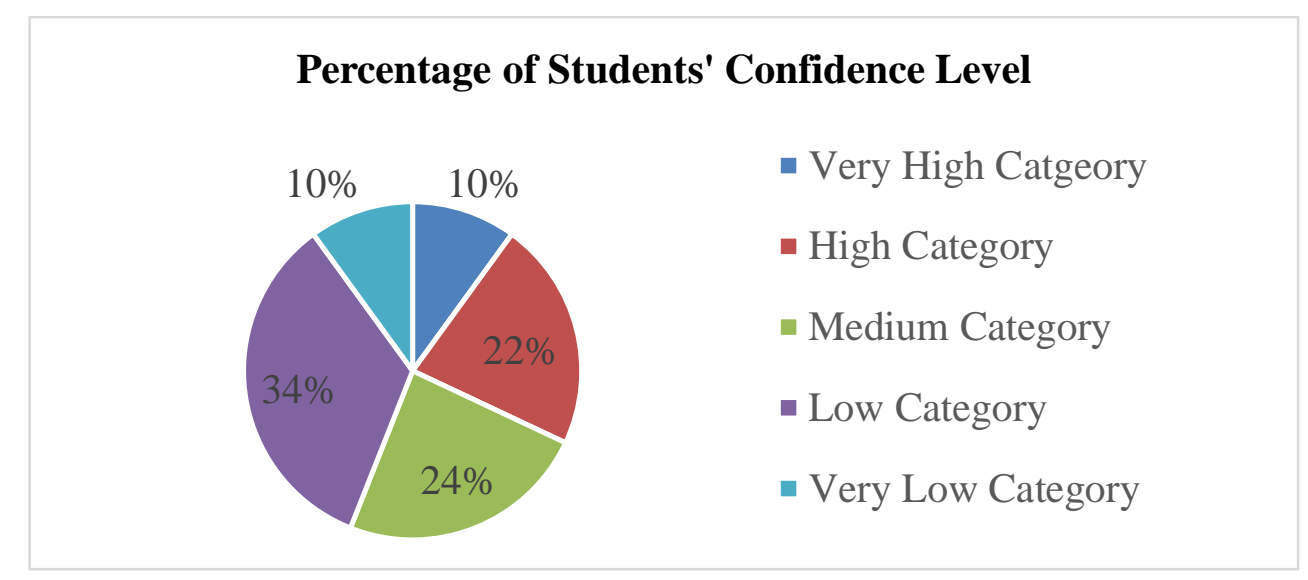

Figure 1. Percentage of Students' Confidence Level

2. Mathematics Anxiety

Mathematics anxiety is a feeling of tension, pressure, anxiety or fear that interferes with math performance. Mathematics anxiety can be defined as an emotional reaction to situations that require or involve mathematics, which interferes with the ability to perform successful mathematical operations (Hamza \& Helal, 2013). The proportion of students' mathematics anxiety level can be seen in figure 2 . 


\section{Percentage of Students' Mathematics Anxiety Level}

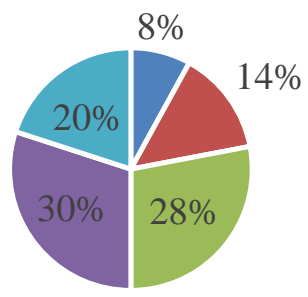

- Very High Catgeory

- High Category

- Medium Category

- Low Category

- Very Low Category

Figure 2. Percentage of Students' Mathematics Anxiety Level

3. Enthusiasm

Students' enthusiasm in learning mathematics can be defined as the feeling of having or showing intense and eager enjoyment, interest, or approval of students in learning mathematics. The proportion of students' enthusiasm toward mathematics level can be seen in figure 3 .

\section{Percentage of Students' Enthusiasm to Mathematics Level}

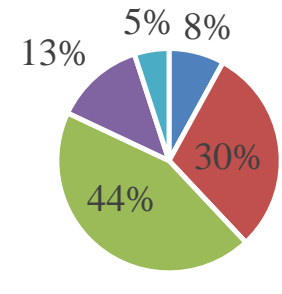

$$
\begin{aligned}
& \text { - Very High Catgeory } \\
& \text { - High Category } \\
& \text { - Medium Category } \\
& \text { - Low Category } \\
& \text { - Very Low Category }
\end{aligned}
$$

Figure 3. Percentage of Students' Enthusiasm to Mathematics Level

4. Self-Regulated Learning

Self-regulated learning is a process when a person can regulate, direct, and control himself in dealing with learning situations that are beneficial to himself. Zimmerman defines self-regulated learning as the ability to learn to actively participate in the learning process, both metacognitive, motivational, and behavioral (Fasikhah \& Fatimah, 2013). The proportion of students' self-regulated level can be seen in figure 4.

\section{Percentage of Students' Self-Regulated Learning Level}

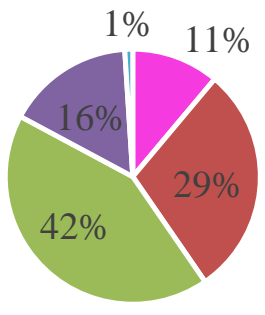

- Very High Catgeory

- High Category

- Medium Category

- Low Category

- Very Low Category

Figure 4. Percentage of Students' Self-Regulated Learning Level 


\section{Mathematical Problem-Solving Ability}

Overall, the student's average score was 62.82 which included in the good assessment category. However, in analyzing students' problem-solving ability, the researcher will focus more on the results of the problem-solving ability of 3 students in 3 categories, namely low, medium, and high categories. To determine the category of students, researchers follow table 3 that adapted from Septianingtyas \& Jusra (2020)

\begin{tabular}{lc}
\multicolumn{3}{l}{ Table 3. Categorization Level of Mathematical Problem Solving Ability } \\
\hline Categories & Values of Mathematical Problem Solving Ability (VOMPSA) \\
\hline High & $75<$ VOMPSA $\leq 100$ \\
Medium & $60<$ VOMPSA $\leq 75$ \\
Low & $0 \leq$ VOMPSA $\geq 60$ \\
\hline
\end{tabular}

For the level of the eighth-grade students is shown in table 4.

\begin{tabular}{|c|c|c|}
\hline Categories & Total Students & Percentage \\
\hline High & 9 & $11 \%$ \\
\hline Medium & 39 & $49 \%$ \\
\hline Low & 31 & $39 \%$ \\
\hline
\end{tabular}

Table 4 shows that a half of samples belonged to the medium level of mathematical problem solving ability based on the category in table 3. Only nine students who have high mathematical problem solving ability.

1. High mathematical problem-solving ability students

High-skilled students can better understand concerns, compile, and carry out plans. By conducting calculations well, neatly, in detail, and clearly, students will simplify problemsolving

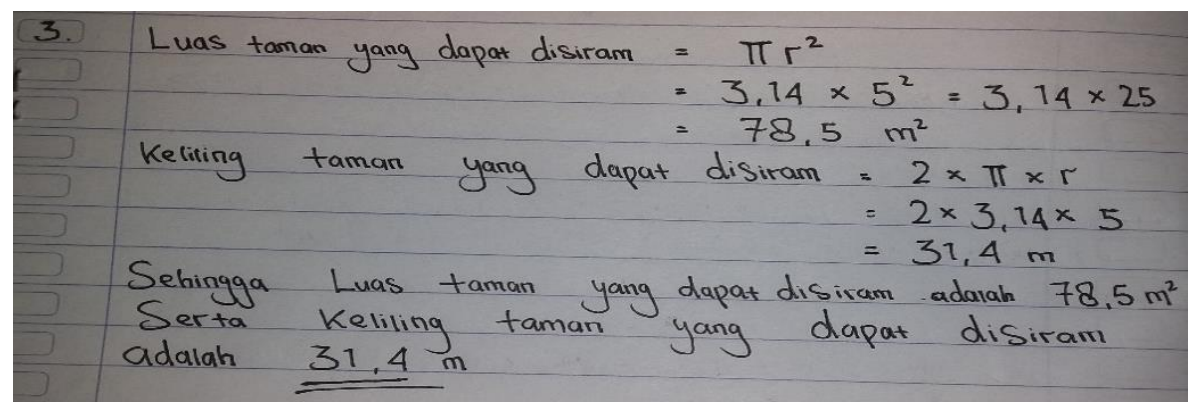

Figure 5. Answer on Question Number 3 from High-Skilled Students

It can be seen in figure 5, the way highly qualified students solve problem number 3, and high-quality students do not fail to look back on the outcomes of the solutions they made. 2. Moderate mathematical problem-solving ability students

The moderate-skilled students also wrote down details about what he learned and what was asked of the problem before solving problem-solving as seen in figure 6 . 


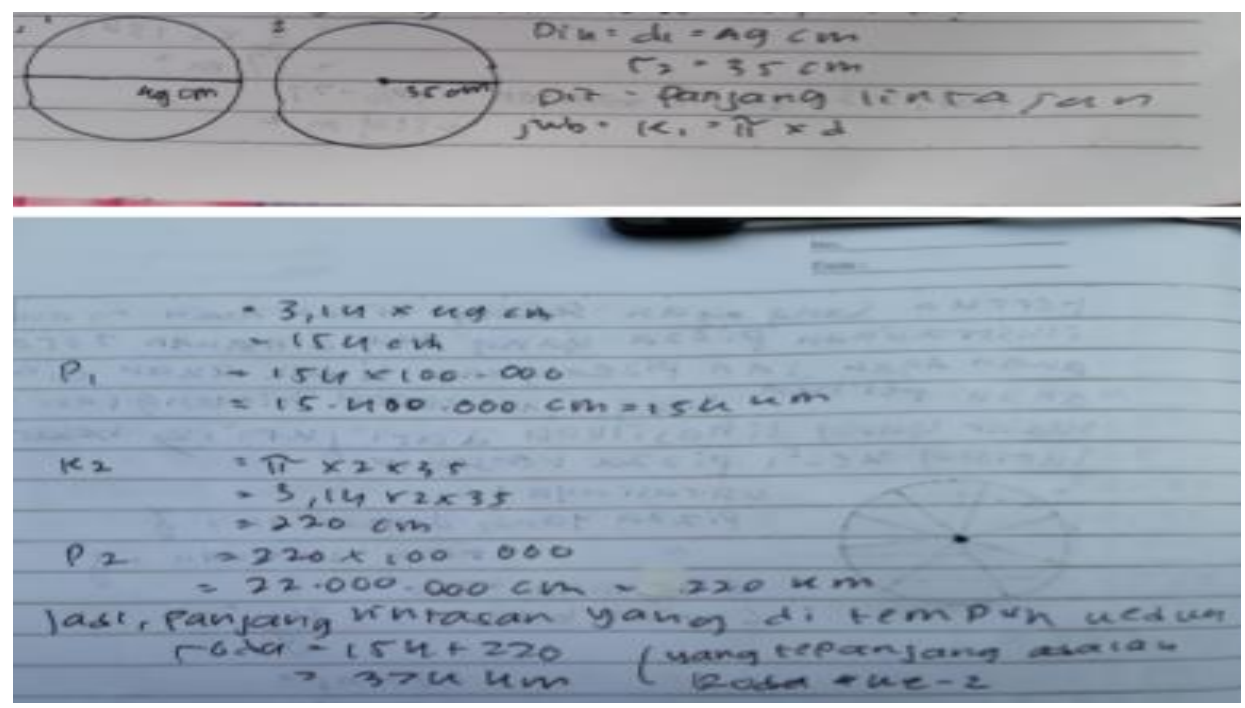

Figure 6. Answer on Question Number 7 from Moderate-Skilled Students

These students can very well understand the problem, compile and execute a plan, this can be seen by the way they can solve problem number 7, add the length of the track taken by the two wheels when solving problem number 7 and then add the length of the track of the first wheel with the length of the second wheel track, although this is not ordered in problem number 7. Students with average skills often do not conclude problem-solving.

3. Low mathematical problem-solving ability students

Low-skilled students can understand problems, formulate and implement plans poorly.

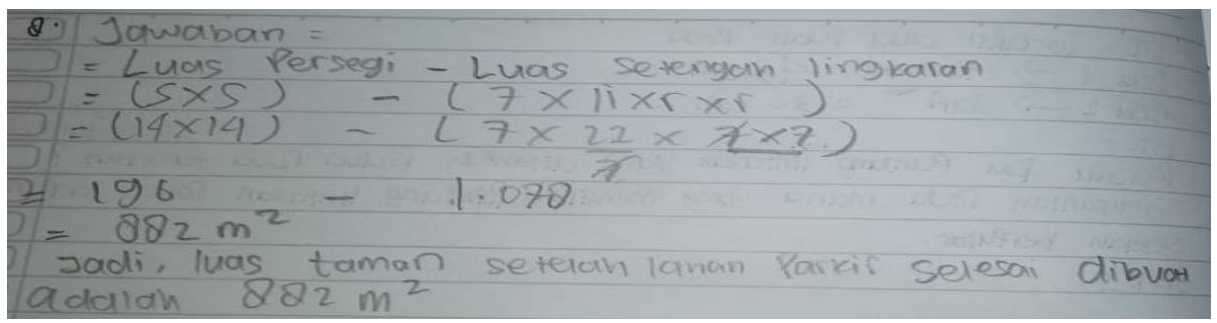

Figure 7. Answer on Question Number 8 from Low-Skilled Students

It can be seen from figure 7 , the way they solve problem number 8 , they are less able to understand the meaning of "the area of a semicircle", they should substitute the value of $1 / 2$ $\times \pi \times \mathrm{r}^{\wedge} 2$ instead of the value $7 \times \pi \times \mathrm{r}^{\wedge} 2$ as the meaning of "area of a semicircle". However, low-skilled students do not forget to re-check the results or solutions of the solutions they make.

After knowing how the students' problem-solving abilities in $8^{\text {th }}$ grade, the researcher will connect the attitudes of high-ability students, medium-capable students' attitudes, and lowability students' attitudes through table 3 . 
Table 5. The Relationship between Student Attitudes and Mathematical Problem Solving Ability

\begin{tabular}{|c|c|c|c|c|}
\hline Li & $\begin{array}{c}\text { Self } \\
\text { Confidence }\end{array}$ & $\begin{array}{l}\text { Mathematics } \\
\text { Anxiety }\end{array}$ & $\begin{array}{l}\text { Mathematics } \\
\text { Enthusiasm }\end{array}$ & $\begin{array}{l}\text { Self-regulated } \\
\text { Learning }\end{array}$ \\
\hline \multicolumn{5}{|l|}{ SUBJECT } \\
\hline $\begin{array}{l}\text { High Ability Students } \\
\text { Moderate Ability Students } \\
\text { Low Ability Students }\end{array}$ & $\begin{array}{l}\text { Very High } \\
\text { Very High } \\
\text { Medium }\end{array}$ & $\begin{array}{l}\text { Medium } \\
\text { Very Low } \\
\text { Low }\end{array}$ & $\begin{array}{l}\text { High } \\
\text { Very High } \\
\text { High }\end{array}$ & $\begin{array}{l}\text { Very High } \\
\text { Very High } \\
\text { High }\end{array}$ \\
\hline
\end{tabular}

Based on table 5, it is known that high-ability students have a very high self-confidence attitude, this is not in accordance with the results of the interview which states that high-skilled students feel very confident in their own mathematical problem-solving abilities.

Students with moderate-skilled have very high self-confidence in their mathematical problem-solving ability, this can also be noticed from the results of interviews with them. The level of self-confidence of low-ability students is in the moderate category, this is by the results of interviews with them. The results of the questionnaire also stated that high-skilled students had a moderate level of mathematics anxiety. The results of the questionnaire of moderate skilled students showed that the level of mathematics anxiety of them was in the very low category. Students with moderate-skilled do not have anxiety about mathematics.

Low-skilled students feel that their mathematics anxiety interferes with their performance in working on mathematical problem-solving ability. This is shown from the results of interviews with them. High-ability students have a high level of enthusiasm towards mathematics. The level of enthusiasm with mathematics can be judged by the way students are serious about doing anything related to mathematics. The level of enthusiasm of high-skilled students towards mathematics is in the high category, this is slightly contradicting the results of interviews with them because they are not serious about doing math problems, and the researcher assumes that the level of student enthusiasm towards mathematics is in the high category of contradiction with the results of the interview.

Moderate-skilled students were very serious when working on the problems of solving mathematical problems. The results of interviews with them by the results of a questionnaire stated that they had a very high level of enthusiastic in mathematics. Low-skilled students feel serious when working on mathematical problem-solving ability. The results of interviews with them are following the results of a questionnaire which states that the level of enthusiastic towards mathematics of them is in the high category.

To measure the level of students' self-regulated learning through interviews, the researcher asked questions that aimed to find out how students set themselves up. The results of the questionnaire stated that the level of self-regulated learning of high-skilled students was in the very high category, this can be proven by the results of interviews with them. From the 
results of the interview, it can be seen that they can control themselves to produce the right answer to the problem of mathematical problem solving ability.

The results of the questionnaire for students with moderate-skilled stated that the level of self-regulated learning of them was in the very high category. This is appropriate because students with moderate ability can control themselves to produce the right answer to the problem of mathematical problem solving ability. Low-skilled students also try to be able to control themselves to produce the right answers to problems in solving mathematical problems.

Based on table 1 along with the results of the interviews, high-skilled students can have an anxiety attitude towards mathematics in the moderate category. This contradicts Güneş Yavuz's statement that high achievement students in mathematics have low math anxiety scores and low achievement students in mathematics have high math anxiety scores (Yavuz, 2018). High-skilled students can have moderate mathematics anxiety because mathematics anxiety does not contribute too much, this is supported by the results of research conducted by Hidayat and Ayudia, the results of their research state that students' mathematical anxiety contributes to influencing problem solving. Mathematics is $57.1 \%$ while the rest $(42.9 \%)$ is not an impact of students' mathematical anxiety (Hidayat and Ayudia 2019). Besides, mathematics anxiety can also have a non-linear relationship with problem-solving ability, this can be seen from the results of another research that students' mathematical anxiety has a non-linear relationship with problem-solving abilities, so that Mathematical anxiety cannot be used to predict problemsolving ability (Aunurrofiq \& Junaedi, 2017). Then, students with low ability can have selfregulated learning attitudes in the high category, this condition can occur because between student attitudes, especially self-regulated learning attitudes, may not have a relationship with problem-solving ability. The statement that students' attitudes, especially self-regulated learning attitudes can have no relationship with problem-solving ability can be proven from the results of research conducted by Elvina, in her research that there is no positive relationship between Self-Regulated Learning and problem-solving ability in mathematics learning (Elvina, 2007).

Furthermore, low-skilled students can have an attitude of self-confidence in the moderate category, because it does not mean that they have self-confidence in the low category either. This condition is almost the same as the results of the research conducted by Putra \& Putri (2018), the results of their research stated that the students' problem-solving ability was still low, but their self-confidence was good, so it could be said that even though students had difficulty solving math problems, it did not weaken their confidence in finding solutions of the problems. 
It can also be assumed that although many high-skilled students have positive attitudes towards mathematics and some low-skilled students have negative attitudes towards mathematics, some high-skilled students have negative attitudes and some low-skilled students have positive attitudes towards mathematics. This is because in influencing the test results the problem-solving ability is not only influenced by attitude factors. There are other internal factors such as the level of intelligence, interests, talents, and motivation explained by Widanti, Murtiyasa, and Ariyanto, they argue that internal factors or factors that come from within the students themselves include the level of intelligence, attitudes, interests, talents and willingness and motivation in mathematics learning (Widanti, Murtiyasa, \& Ariyanto, 2018). Also, there are external factors that can affect students' mathematical problem-solving ability.

The presence of high-skilled students who have negative attitudes towards mathematics as well as low-skilled students but have positive attitudes towards mathematics can be caused because attitudes are only one of the many factors that affect students' mathematical problemsolving abilities. Low or high levels of mathematical problem-solving ability can be caused by different factors by students, such as research conducted by Kudsiyah, Novarina, and Lukman, their research results state that there are eight factors that have a significant influence on students' mathematical problem-solving ability in order: 1) Learning difficulties have an effect of $25 \%$; 2) Attitude (like / dislike) has an effect of $14.44 \%$; 3 ) Attention has the effect of $9.61 \%$; 4) Laziness has the effect of $9 \%$; 5) The formula has an effect of 7.84\%; 6) The response has an effect of $7.29 \%$; 7) the Previous study has an effect of $6.76 \%$; and 8) Motivation $5.76 \%$ (Kudsiyah, Novarina, and Lukman, 2017).

\section{CONCLUSION}

The findings showed that most learners were both enthusiastic and apathetic about mathematics. The key reason students are eager for mathematics is that they can enhance their talents, skills, and knowledge. Meanwhile, most of them think mathematics is complicated for students who are not interested in mathematics. Besides, it showed that most of the students have a low category on self-confidence and anxiety towards mathematics, and have an enthusiastic attitude towards mathematics and self-regulated learning in the moderate category. 8 students (around 10\%) have a very high level of self-confidence, 17 students (around 22\%) have a high level of self-confidence, 19 students (around 24\%) have a moderate level of selfconfidence, 27 students (around 34\%) have a low level of self-confidence, and the rest have a very low level of self-confidence. For each level of math anxiety namely very high, high, moderate, low, and very low, the proportion number of students is 6 students, 11, students, 22 
students, 24 students, and 16 students respectively. The number of the proportion of enthusiastic level on mathematics are 6 students, 24 students, 35 students, 10 students, and 4 students with the identical sequences of category for math anxiety. Likewise, self-regulated learning level, with the identical sequences level there are 9 students, 23 students, 33 students, 13 students, and 1 student. The average value of students' mathematical problem-solving ability was in the good assessment category.

\section{REFERENCES}

Akinmola, E. A. (2014). Developing Mathematical Problem Solving Ability: a Panacea for a Sustainable Development in the 21 St Century By Science and Technical Education Department ,. International Journal of Education and Researc, 2(2), 1-8.

Ariani, S., Hartono, Y., \& Hiltrimartin, C. (2017). Kemampuan Pemecahan Masalah Matematika Siswa pada Pembelajaran Matematika Menggunakan Strategi AbduktifDeduktif di SMA Negeri 1 Indralaya Utara. Jurnal Elemen, 3(1), 25. https://doi.org/10.29408/jel.v3i1.304

Atan, M., \& Kasmin, F. (2018). Assessing Mathematicsâ€ TM Attitude among Technical University Students. International Journal of Academic Research in Business and Social Sciences, 7(14), 103-115. https://doi.org/10.6007/ijarbss/v7-i14/3655

Aunurrofiq, M., \& Junaedi, I. (2017). Kecemasan Matematik Siswa dalam Menyelesaikan Soal-Soal Pemecahan Masalah. Unnes Journal of Mathematics Education Research, 6(2), 157-166.

Elvina, A. (2007). Hubungan antara Self Regulated Learning Dengan Kemampuan Memecahkan Masalah Pada Pembelajaran Matematika Pada Siswa SMUN 53 Di Jakarta Timur.

Escalera Chávez, M. E., Moreno García, E., \& Rojas Kramer, C. A. (2018). Confirmatory Model to Measure Attitude towards Mathematics in Higher Education Students: Study Case in SLP Mexico. International Electronic Journal of Mathematics Education, 14(1), 163-168. https://doi.org/10.29333/iejme/3984

Fasikhah, S. S., \& Fatimah, S. (2013). Self-Regulated Learning (SRL) dalam Meningkatkan Prestasi Akademik pada Mahasiswa. Jurnal Ilmiah Psikologi Terapan, 01(01), 145- 
155.

Hamza, E. G. A., \& Helal, A. M. (2013). Maths Anxiety in College Students across Majors: A Cross-Cultural Study. Educationalfutures, 5(2), 58-74.

Hidayat, F., Akbar, P., \& Bernard, M. (2018). Analisis kemampuan berfikir kritis matematik serta kemandiriaan belajar siswa smp terhadap materi SPLDV. Journal On Education, 01(02), 515-523.

Hidayat, W., \& Ayudia, D. B. (2019). Kecemasan Matematik Dan Kemampuan Pemecahan Masalah Matematis Siswa Sma. Kalamatika: Jurnal Pendidikan Matematika, 4(2), 205-214. https://doi.org/10.22236/kalamatika.vol4no2.2019pp205-214

Ibrahim, M. (2018). Peningkatan Kepercayaan Diri Siswa Terhadap Matematika Dengan Menggunakan Pendekatan Ctl (React). Jurnal Tatsqif, 16(1), 55-77. https://doi.org/10.20414/jtq.v16i1.133

Kudsiyah, S. M., Novarina, E., \& Lukman, H. suryani. (2017). Faktor-Faktor Yang Mempengaruhi Kemampuan Pemecahan Masalah Matematika Kelas X Di Sma Negeri 2 Kota Sukabumi. Education: Prodi Pendidikan Matematika FKIP Universitas Muhammadiyah Sukabumi, 110-117.

Mazana, M. Y., Montero, C. S., \& Casmir, R. O. (2018). Investigating Students' Attitude towards Learning Mathematics. International Electronic Journal of Mathematics Education, 14(1), 207-231. https://doi.org/10.29333/iejme/3997

Putra, H. D., \& Putri, W. A. S. (2018). Kemampuan Pemecahan Masalah Matematis dan SelfConfidence Siswa SMP. SJME (Suoremum Journal of Mathematics Education), 2(1), $60-70$.

$\begin{array}{lllllll}\text { Rajkumar, } & \text { R., } & \& & \text { Hema, } & \& & \text { G. } & \text { (2019). }\end{array}$ Factors_Affecting_Mathematical_Problem_Solving_Competence_of_Undergraduate_ Students_in_Facing_Competitive_Examinations-2019-02-22-10-07, 7(2), 319-328.

Septianingtyas, N., \& Jusra, H. (2020). Kemampuan Pemecahan Masalah Matematis Peserta Didik Berdasarkan Adversity Quotient. Jurnal Cendekia: Jurnal Pendidikan Matematika Volume, 4(2). 
Sezgin memnun, D., \& ÇOBAN, M. (2015). Mathematical Problem Solving: Variables that Affect Problem Solving Success. International Research in Education, 3(2), 110. https://doi.org/10.5296/ire.v3i2.7582

Waheed, H., \& Mohamed, L. (2011). Secondary Students' Attitude towards Mathematics in a Selected School of Maldives. International Journal of Humanities and Social Science, 1(15), 277-281.

Widanti, F. N., Murtiyasa, B., \& Ariyanto. (2018). Upaya Meningkatkan Kemampuan Penalaran Matematis Siswa Melalui Model Pembelajaran CORE (Connecting, Organizing, Reflecting, Extending). Journal of Chemical Information and Modeling, 53(9), 1689-1699.

Yavuz, G. (2018). Mathematics Anxiety of Ninth Grade Students. Journal of Education and Training Studies, 6(5), 21. https://doi.org/10.11114/jets.v6i5.3044 